\title{
THE T-CELL RECEPTOR ALPHA, BETA AND GAMMA POLYMORPHISM IN JAPANESE
}

\author{
Juan M. R. Aparicio, ${ }^{1}$ Akemi WaKisaka, ${ }^{1}$ Akio Takada, ${ }^{1}$ \\ Nobuo MatsuUra, ${ }^{2}$ and Takashi YoshIKI ${ }^{1}$ \\ Departments of ${ }^{1}$ Pathology and ${ }^{2}$ Pediatrics, Hokkaido University School of Medicine, \\ Kita-ku, Sapporo 060, Japan
}

\begin{abstract}
Summary Polymorphism in the genes encoding the alpha $(\alpha)$, beta $(\beta)$ and gamma $(\gamma)$ chains of the human T-cell receptors was analyzed both in population and family: studies. Against twelve unrelated Japanese, several out of the 15 restriction endonucleases tested, revealed restriction fragment length polymorphism. The segregation of the polymorphic fragments were confirmed among 15 members of three families. In most of the cases paternal and/or maternal haplotypes could be assigned. By testing the polymorphic enzymes among the random healthy Japanese, the frequency of each polymorphic fragment was then determined. Although the polymorphism found in this study was similar to that reported in Caucasians, some differences were observed. Such differences are discussed. The restriction fragment length polymorphism in both population and family studies, derived from $\alpha, \beta$ and $\gamma$ chains of the T-cell receptor found in this report, might be useful markers for genetic analysis of the T-cell function in relation to immunological disorders.
\end{abstract}

Key Words restriction fragment length polymorphism (RFLP), T-cell receptors $\alpha, \beta$ and $\gamma$ chains

\section{INTRODUCTION}

T-cell antigen receptor (TCR), a cell surface protein heterodimer consisting of an acidic $\alpha$, a basic $\beta$, a third $\gamma$ (Haskins et al., 1983, Meuer et al., 1983; Saito et $a l ., 1984)$ and a fourth $\delta$ chain, have recently been cloned, allowing the use of restriction fragment length polymorphism (RFLP) for a better understanding of the structure and organization of the TCR genes (Kronenberg et al., 1986).

The analysis of genes polymorphism of the TCR involved in immune processes

Received March 23, 1989; revised version received October 11, 1989; Accepted October 31, 1989. Offprint request to: J. M. Aparicio, Department of Pathology, Hokkaido University School of Medicine, N-15, W-7, Kita-ku, Sapporo 060, Japan. 
has provided new markers for the study of genetic variability in the immune response of several autoimmune diseases (Hoover et al., 1986a, b; Demaine et al., 1986, 1988; Millward et al., 1987; Vladutiu and Rose, 1975; Wofsy et al., 1985; Bottazzo et al., 1985; Goldstein et al., 1987).

This study describes the results obtained by TCR $\alpha, \beta$ and $\gamma$ restriction fragment length polymorphism (RFLP) analysis in Japanese, that is which enzyme shows polymorphism and also the size and frequency of such polymorphic fragments within groups of healthy individuals. An attempt was also made to confirm the segregation of these polymorphism by using three families.

Although $\mathrm{T}$ cell receptors has been widely studied among Caucasians (Robinson and Kindt, 1985a, b; So et al., 1987), few investigation has been performed in Japanese. Therefore, we believe that the polymorphism and segregation described here might be useful for further genetic studies especially in relation to the susceptibility of immunological disorders.

\section{MATERIALS AND METHODS}

1. Population and family studies. At the beginning, twelve unrelated Japanese were used to find the polymorphic enzyme in relation to each gene. The segregation of this polymorphism was confirmed by using three families, which were consisted with parents and several children. Up to 46 unrelated individuals were used to determine the frequency of the polymorphic fragments, confirmed in the family studies by the different polymorphic enzymes.

2. $c D N A$ probes. The three $\mathrm{T}$-cell receptor cDNA probes used in this study were kindly provided by Dr. Tak Mak.

The T-cell receptor $\alpha$ chain probe was obtained from the human cDNA clone pY14 digested with EcoRI. The pY14 clone contains an insert of 1,101 pb that corresponds to the $5^{\prime}$-untranslated region, leader sequence, $\mathrm{V}, \mathrm{D}, \mathrm{J}$ and $\mathrm{C}$ regions and $3^{\prime}$-untranslated sequences (Yanagi et al., 1985).

The T-cell receptor $\beta$ chain probe, a $770 \mathrm{bp}$, was cloned into Pst I site of pBR322. This probe contains $J$ and $C$ regions of TCR $\beta$ gene (Yanagi et al., 1984).

The T-cell receptor $\gamma$ chain probe, a $1.6 \mathrm{~kb}$ insert containing $\mathrm{V}, \mathrm{J}$ and $\mathrm{C}$ regions were cloned into EcoRI site (Yoshikai et al., 1987). HindIII was used to separate variable (V) and joining (J) fragments from the constant (C) region.

3. RFLP analysis. RFLP analysis was performed as previously reported (Aparicio et al., 1988). Fifteen enzymes (BglI, HaelI, EcoRI, HindIII, MspI, HaeIII, HinfI, HincII, StyI, PstI, XbaI, PvuII, BglII (at $37^{\circ} \mathrm{C}$ ), BamHI (at $30^{\circ} \mathrm{C}$ ) and $\operatorname{Taq} \mathrm{I}\left(\right.$ at $65^{\circ} \mathrm{C}$ ) were used to find the polymorphic enzymes.

4. Statistical analysis. Allelism of the polymorphic fragments were confirmed by chi-square analysis whether the distribution of the given fragment combination were in Hardy-Weinberg's equilibrium. 


\section{RESULTS AND DISCUSSION}

Since several disorders has been found to have an autoimmune basis, T-cell receptors of the lymphocytes have been widely investigated. For example, the T-cell receptor $\beta$ was observed to be associated with insulin dependent diabetes mellitus in Caucasians (Hoover et al., 1986a, b; Demaine et al., 1986, 1988; Millward et al., 1987) differently than in Japanese (Aparicio et al., submitted for publication). This report demonstrates RFLP analysis of the possible genes encoding for $\alpha, \beta$ and $\gamma$ chain of the human T-cell receptors in Japanese. A summary of the polymorphic enzymes found here is shown in Table 1 .

\section{Polymorphism in the $T$-cell receptor $\alpha$ gene}

By means of Southern blot analyses, twelve DNA samples were digested with 15 restriction endonucleases by using a probe that correspond to the human T-cell receptor $\alpha$ chain (Yanagi et al., 1985). Three out of the 15 enzymes presented

Table 1. Polymorphic restriction enzymes and their respective fragments for the T-cell receptor $\alpha, \beta$, and $\gamma$ in Japanese.

\begin{tabular}{|c|c|c|c|}
\hline \multirow{2}{*}{ Probe/enzyme } & \multicolumn{2}{|c|}{ Polymorphic fragments } & \multirow{2}{*}{$\begin{array}{l}\text { Invariant fragments } \\
(\mathrm{kb})\end{array}$} \\
\hline & $\begin{array}{l}\text { Single } \\
(\mathrm{kb})\end{array}$ & $\begin{array}{c}\text { Diallelic } \\
(\mathrm{kb})\end{array}$ & \\
\hline \multicolumn{4}{|l|}{$\operatorname{TCR} \alpha$} \\
\hline TaqI & (1.4) & $7.4 / 2.2$ & $3.5,2.6,1.5,1.2,0.9$ \\
\hline$P_{v u \amalg[\mathrm{b}}$ & - & $5.2 / 4.3$ & $7.8,4.9,(1.2),(1.1)$ \\
\hline EcoRIb & 13.2 & - & $16.5,8.4,2.7,2.1$ \\
\hline \multicolumn{4}{|l|}{ TCR $\beta$} \\
\hline BglII & - & $9.0 / 8.4$ & $2.3,1.3$ \\
\hline $\operatorname{Taq} \mathrm{I}$ & $7.0^{2}$ & - & $5.0,3.4,(2.3), 1.7$ \\
\hline BamHI & $11.5^{\mathrm{a}}$ & - & 21.0 \\
\hline \multicolumn{4}{|l|}{ TCR $\gamma$} \\
\hline $\operatorname{Taq} \mathrm{I}$ & - & $2.8 / 2.1(\mathrm{C})$ & $6.2(\mathrm{C}), 3.9(\mathrm{C}), 2.5(\mathrm{C})$ \\
\hline$X b a \mathbf{I}$ & $3.9(\mathrm{C})$ & $7.0 / 6.7(\mathrm{VJ})$ & $10.0(\mathrm{C}), 3.5(\mathrm{C}), 3.2(\mathrm{C}), 2.3(\mathrm{C})$ \\
\hline Msp I & - & $7.2 / 5.2(\mathrm{C}), 1.2 / 1.0(\mathrm{VJ})$ & $4.7(\mathrm{C}), 4.3(\mathrm{C}), 3.9(\mathrm{C})$ \\
\hline Pst $\mathrm{I}$ & $3.7(\mathrm{C})$ & - & $4.1(\mathrm{~J}), 2.3(\mathrm{C}), 1.8(\mathrm{C}), 1.5(\mathrm{C})$ \\
\hline$P v u \mathrm{II}^{\mathrm{b}}$ & $10.0(\mathrm{C})$ & - & $11.2(\mathrm{C}), 8.0(\mathrm{C}), 3.2(\mathrm{VJ})$ \\
\hline$B g l \mathrm{I} b$ & & $21.0 / 12.0(\mathrm{VJ}), 19.0 / 4.4(\mathrm{C})$ & - \\
\hline
\end{tabular}

( ) faint bands. a Polymorphic fragments which did not segregate to the offsprings. b Enzymes which were not tested among the population studies. (C), fragments derived from the constant region. $(V, J)$, fragments derived from the variable and joining regions. 
polymorphic fragments. They are, $\operatorname{Taq} \mathrm{I}(7.4,3.5,2.6,2.2,1.5,1.4,1.2,0.9 \mathrm{~kb})$, $P v u I I(7.8,5.2,4.9,4.3,3.3,1.2,1.1 \mathrm{~kb})$ and $E c o R I(16.5,13.2,8.4,2.7,2.1 \mathrm{~kb})$. Among these fragments, the 7.4 and $2.2 \mathrm{~kb}$ of Taq $\mathrm{I}$ showed mutually allelic distribution. This allelism was confirmed by family and population studies, that is the number of individuals carrying these specific fragment combinations were similar to those expected by Hardy-Weinberg's equilibrium. 5.2 and $4.3 \mathrm{~kb}$ of $P v u \mathrm{II}$ fragments were also suggested to be allelic by family segregation.

Table 2 shows the frequency of $T a q \mathrm{I}$ among a group of healthy individuals.

The polymorphic fragments were compared to those reported in Caucasians,

Table 2. Frequency of the T-cell receptor $\alpha, \beta$ and $\gamma$ among healthy Japanese.

\begin{tabular}{|c|c|c|c|c|}
\hline & \multirow{2}{*}{ Enzyme } & \multirow{2}{*}{ Fragment size } & \multicolumn{2}{|c|}{ Frequency } \\
\hline & & & Number & $\%$ \\
\hline \multicolumn{5}{|l|}{$\operatorname{TCR} \alpha$} \\
\hline & \multirow[t]{5}{*}{$\operatorname{Taq} \mathrm{I}$} & $7.4 / 7.4$ & $3 / 24$ & 12.5 \\
\hline & & $7.4 / 2.2$ & $12 / 24$ & 50.0 \\
\hline & & $2.2 / 2.2$ & $9 / 24$ & 37.5 \\
\hline & & Total & 24 & \\
\hline & & 1.4 & $9 / 24$ & 37.5 \\
\hline \multicolumn{5}{|l|}{$\operatorname{TCR} \beta$} \\
\hline & \multirow[t]{4}{*}{$B g l I I$} & $9.0 / 9.0$ & $1 / 23$ & 4.3 \\
\hline & & $9.0 / 8.4$ & $9 / 23$ & 39.1 \\
\hline & & $8.4 / 8.4$ & $13 / 23$ & 56.5 \\
\hline & & Total & 23 & \\
\hline \multicolumn{5}{|l|}{ TCRr } \\
\hline & \multirow[t]{4}{*}{ TaqI } & $2.8 / 2.8$ & $3 / 24$ & 12.5 \\
\hline & & $2.8 / 2.1$ & $10 / 24$ & 41.6 \\
\hline & & $2.1 / 2.1$ & $11 / 24$ & 45.8 \\
\hline & & Total & 24 & \\
\hline & Pst I & 3.7 & $3 / 16$ & 18.7 \\
\hline \multirow{5}{*}{\multicolumn{2}{|c|}{ XbaI }} & $7.0 / 7.0$ & $0 / 53$ & 0.0 \\
\hline & & $7.0 / 6.7$ & $8 / 53$ & 15.1 \\
\hline & & $6.7 / 6.7$ & $45 / 53$ & 84.9 \\
\hline & & Total & 53 & \\
\hline & & 3.9 & $23 / 53$ & 43.4 \\
\hline \multirow{8}{*}{\multicolumn{2}{|c|}{$M s p I$}} & $7.2 / 7.2$ & $5 / 38$ & 13.2 \\
\hline & & $7.2 / 5.2$ & $25 / 38$ & 65.8 \\
\hline & & $5.2 / 5.2$ & $8 / 38$ & 21.1 \\
\hline & & Total & 38 & \\
\hline & & $1.2 / 1.2$ & $8 / 38$ & 21.1 \\
\hline & & $1.2 / 1.0$ & $22 / 38$ & 57.9 \\
\hline & & $1.0 / 1.0$ & $8 / 38$ & 21.1 \\
\hline & & Total & 38 & \\
\hline
\end{tabular}


as an example, although there is a small variation on the molecular weight of the TaqI polymorphic 7.4, 2.2 and $1.4 \mathrm{~kb}$ fragments, they seem to be similar to those 8.0, 2.1, 1.0 (Robinson and Kindt, 1987) or 7.0, 2.0 and $1.4 \mathrm{~kb}$ (So et al., 1987) fragments found in Caucasians. Moreover, it was demonstrated by hybridizing with a $\mathrm{C}_{\alpha}$ probe, that the allelic polymorphism of 8.0 and $2.1 \mathrm{~kb}$ bands $(7.4$ and $2.2 \mathrm{~kb}$ in our study), seem to be due to changes in restriction sites around the exon 1 of $\mathrm{C}$ gene, whereas the $1.0 \mathrm{~kb}(1.4 \mathrm{~kb}$ in our study) due to the polymorphism of the V gene (Robinson and Kindt, 1987; So et al., 1987). On the contrary, polymorphic fragments of $M s p \mathrm{I}-4.5 \mathrm{~kb}$ and $B g l \mathrm{II}-3.0 \mathrm{~kb}$ found in Caucasians were observed as invariant chains of 4.3 and $2.8 \mathrm{~kb}$ respectively in Japanese.

Polymorphism in the T-cell receptor $\beta$ genes

By using a probe which correspond to the $C$ region of the $\beta$ chain (containing $\mathrm{J}$ and $\mathrm{C}$ regions) of the human T-cell receptor (C) (Yoshikai et al., 1984), where only 3 enzymes showed polymorphism. $\operatorname{Bg} / \mathrm{II}(9.0,8.4,2.3,1.3 \mathrm{~kb}), \operatorname{Taq} \mathrm{I}(7.0$, $5.0,3.4,2.3,1.7 \mathrm{~kb})$ and $B a m H I(21.0,11.5 \mathrm{~kb})$. The $B g / I \mathrm{I}-9.0 / 8.4 \mathrm{~kb}$ fragments were allelic, and seems to be similar to those reported in Caucasians (Robinson and Kindt, 1985a, b). Polymorphic fragments of BamHI (11.5 kb) and TaqI (7.0 $\mathrm{kb}$ ) showed faint bands and family segregation was not confirmed (Fig. 1, A and $B$, respectively). These unexpected segregation of the TCR $\beta$ genes were also

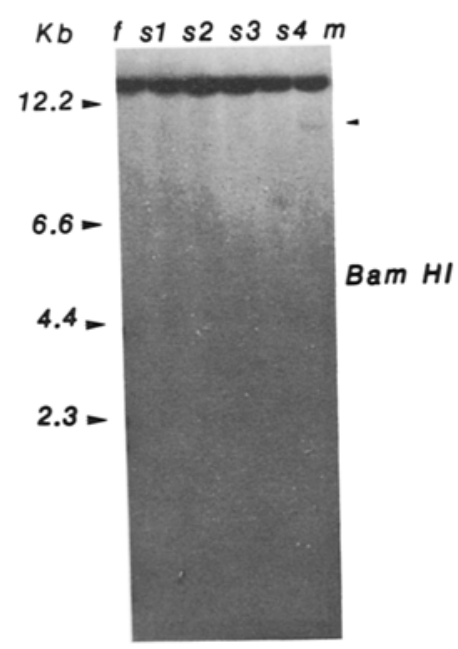

A family 2

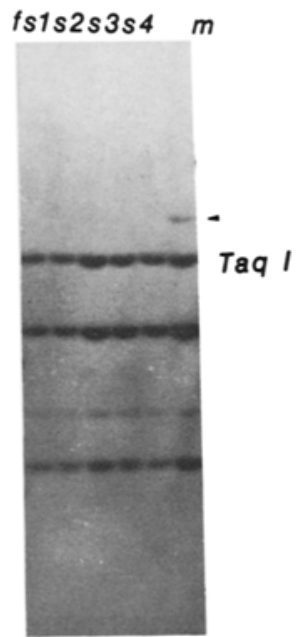

B family 2

Fig. 1. Segregation of the TCR $\beta$ RFLP in family 2. The donors of DNA in the gel lanes are, father (f), mother (m) and children 1-4 (s1-s2) in this family. A) DNA samples were digested with BamHI, B) with TaqI and then hybridized with TCR $\beta \mathbf{J}$ and $\mathbf{C}$ regions probe (Yanagi et al., 1984). 
reported in Caucasians (Robinson et al., 1985a), due to rearrangement or some other alteration in the germ line configuration. They found a BamHI-15.0 kb fragment in one of the children, although both parents lacked it. The relationship between $B a m \mathrm{HI} 11.5 \mathrm{~kb}$ polymorphic fragment found in this study, and the 15.0 $\mathrm{kb}$ fragment in Robinson's were unclear.

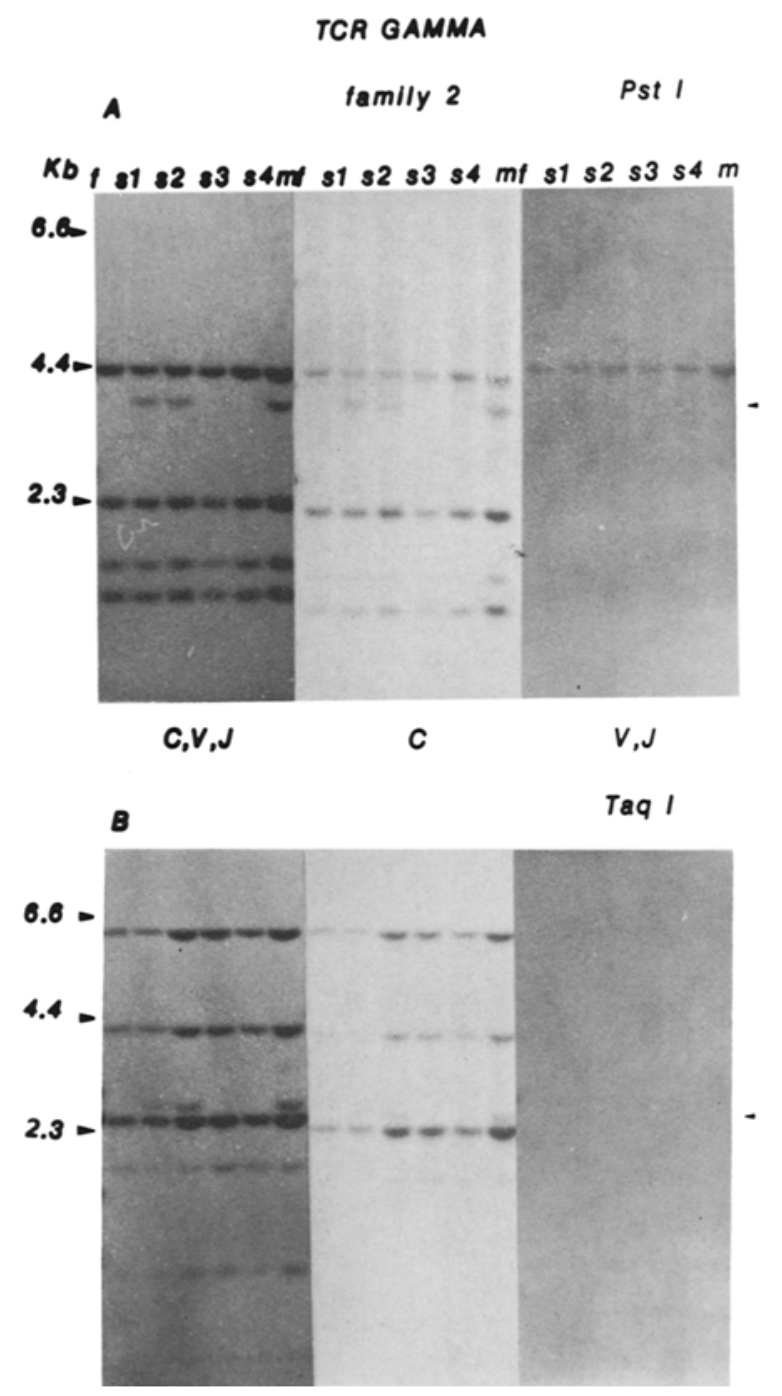

Fig. 2. Segregation of the TCR $r$ RFLP in family 2. The donors of DNA in the gel lanes are, father (f), mother (m) and children 1-4 (s1-s2) in this family. A) DNA samples were digested with $P_{s t} \mathrm{I}, \mathrm{B}$ ) with $T a q \mathrm{I}$. All the blot was hybridized with TCR $\gamma$ V,J and C regions probe (Yoshikai et al., 1987). The samples were also re-hybridized with the constant region $(C)$ and variable and joining regions $(V$, J) separately. 
Table 2 shows the frequency of $B g l I I$ among a group of healthy individuals.

\section{Polymorphism in the $T$-cell receptor $\gamma$ gene}

Restriction fragment length polymorphism associated with the T-cell receptor $\gamma$ which correspond to the $\mathrm{V}, \mathrm{J}$ and $\mathrm{C}$ region (Yoshikai et al., 1987) was also studied among the unrelated Japanese and three families. Moreover, in order to find more precisely the TCR $\gamma$ probes were divided into 2 fragments, the $\mathrm{V}$ and $\mathrm{J}$ regions of the TCR $\gamma$ and that of $\mathrm{C}$ region. These specific probes were used separately to determine the origins of the fragments.

TCR $\gamma$ polymorphic fragments were observed in 6 enzymes; $X b a \mathrm{I}(10.0,7.0$, 6.7, 3.9, 3.5, 3.2, $2.3 \mathrm{~kb}), \operatorname{Taq} \mathrm{I}(6.2,3.9,2.8,2.5,2.1 \mathrm{~kb})$, Pst I (4.1, 3.7, 2.3, 1.8, 1.5 kb), MspI $(7.2,5.2,4.7,4.3,3.9,1.2,1.0 \mathrm{~kb}), p_{v u I I}(11.2,10.0,8.0,3.2 \mathrm{~kb}), B g I \mathrm{I}$ $(21.0,19.0,12.0,4.4 \mathrm{~kb})$. Among these fragments, allelism was also present, the TaqI-2.8 kb / $2.1 \mathrm{~kb}, X b a \mathrm{I}-7.0 \mathrm{~kb} / 6.7 \mathrm{~kb}$. In addition, two di-allelic polymorphism, $21.0 \mathrm{~kb} / 12.0 \mathrm{~kb}, 19.0 \mathrm{~kb} / 4.4 \mathrm{~kb}$ and $7.2 \mathrm{~kb} / 5.2 \mathrm{~kb}, 1.2 \mathrm{~kb} / 1.0 \mathrm{~kb}$, were demonstrated when $B g l \Gamma$ and $M s p I$ were applied respectively. The polymorphic $P v u \mathrm{II}-10.0 \mathrm{~kb}$ fragment in Japanese differs completely from allelic polymorphism of $P v u \mathrm{II}-20.0,17.0$ and $15.0 \mathrm{~kb}$ fragments found in Caucasians (Dunckley et al., 1988). Pst I and TaqI polymorphism, so far as we know, of TCR $\gamma$ has not reported yet in Caucasian which we could confirm in Japanese. As an example, segregation of Pst I and TaqI fragments in family 2 were shown in Fig. 2, A and B, where the polymorphic $P s t \mathrm{I}-3.7 \mathrm{~kb}$ and $T a q \mathrm{I}-2.9 \mathrm{~kb}$ fragments were inherited by two children from the mother. These results indicated some differences might be present in TCR genes among the ethnic groups.

The frequencies of $M s p \mathrm{I}, T a q \mathrm{I}, P s t \mathrm{I}, B g l \mathrm{I}$, and $X b a \mathrm{I}$ polymorphic fragments are shown in Table 2.

By means of RFLP, the genes encoding the $\alpha, \beta$ and $\gamma$ chains of the human T-cell receptors and their segregation among families have been analyzed. The purpose of this study was then to find the possible polymorphism in Japanese and to analyze their frequency. Therefore, we believe that this polymorphism could provide useful markers, which together with the restriction fragment length polymorphism of the HLA region might contribute to a better understanding of the gene complex which is responsible for the development of the various immunological disorders.

Acknowledgments. The authors are very grateful to Dr. Tak Mak for providing the three T-cell receptor cDNA probes, and to Mr. K. Masuda, Ms. M. Keira, and Ms. Watabe for their excellent technical assistance.

This work was supported in part by the Research Grant for the Intractable Diseases from the Ministry of Health and Welfare of Japan, and by a Grant-in-Aid for scientific research (No. 62570210) from the Ministry of Education, Science and Culture of Japan. 


\section{REFERENCES}

Aparicio, R.J.M., Wakisaka, A., Takada, A., Matsuura, N. and Aizawa, M. 1988. HLA-DQ system and insulin-dependent diabetes mellitus in Japanese: does it contribute to the development of IDDM as it does in Caucasians? Immunogenetics 28: 240-246.

Bottazzo, G.F., Dean, B.M., McNally, J.M., MacKay, E.H., Swift, P.G.F. and Gamble, D.R. 1985. In situ characterization of autoimmune phenomena and expression of HLA molecules in the pancreas in diabetic insulitis. New Eng. J. Med. 313: 353-360.

Demaine, A.G., Millward, B.A., Leslie, R.D.G. and Welsh, K.I. 1986. T cell receptor beta chain gene polymorphisms are associated with insulin-dependent diabetes (IDD) in identical twins. Diabetic Med. 3: 567A.

Demaine, A.G., Vaughan, R.W., Taube, D.H. and Welsh, K.I. 1988. Association of membranous nephropathy with T-cell receptor constant $\beta$ chain and immunoglobulin heavy chain switch region polymorphisms. Immunogenetics 27: 19-23.

Dunckley, H., Gatenby, P.A. and Serjeantson, S.W. 1988. T-cell receptor and HLA class II RFLPs in systemic lupus erythematosus. Immunogenetics 27 ; 392-395.

Goldstein, R., Krupen, K., Crawford, Y.M., Arnett, F.C. and Duvic, M. 1987. The T cell receptor beta chain and systemic lupus erythematosus. Clin. Res. 35: 86.

Haskins, K., Kubo, R., White, J., Pigeon, M., Kappler, J. and Marrack, P. 1983. The major histocompatibility complex-restricted antigen receptor on $\mathbf{T}$ cells $\mathrm{I}$. Isolation with a monoclonal antibody. J. Exp. Med. 157: 1149-1169.

Hoover, M.L., Angelini, G., Ball, E., Ferrara, G.B., Marks, J., Raskin, P., Rosenstock, J., Stastny, P., Tosi, R. and Capra, J.D. 1986a. Insulin-dependent diabetes mellitus is associated with polymorphic forms of the $T$ cell receptor beta chain gene. Meeting abstract. Cold Spring Harbor Symp. Quant. Biol. 51: 24.

Hoover, M.L., Angelini, G., Ball, E., Stastny, P., Marks, J., Rosenstock, J., Raskin, P., Ferrara, G.B., Tosi, R. and Capra, J.D. 1986b. HLA-DQ and T-cell receptor genes in insulin-dependent diabetes mellitus. Cold Spring Harbor Symp. Quant. Biol. 51: 803-809.

Kronenberg, M., Siu, G., Hood, L.E. and Shastri, N. 1986. The molecular genetics of the T-cell antigen receptor and T-cell antigen recognition. Annu. Rev. Immunol. 4: 529-591.

Meuer, S.C., Fitzgerald, K.A., Hussey, R.E., Hodgdon, J.C., Schlossman, S.F. and Reinherz, E.L. 1983. Clonotypic structures involved in antigen-specific human $\mathrm{T}$ cell function. Relationship to the T3 molecular complex. J. Exp. Med. 157: 705-719.

Millward, B.A., Welsh, K.I., Leslie, R.D.G., Pyke, D.A. and Demaine, A.G. 1987. T cell receptor beta chain polymorphisms are associated with insulin-dependent diabetes. Clin. Exp. Immunol. 70: 152-157.

Robinson, M.A. and Kindt, T.J. 1985a. Molecular determination of T-cell receptor $\alpha$ and $\beta$ chain genotypes in human families. Hum. Immunol. 14: 195-205.

Robinson, M.A. and Kindt, T.J. 1985b. Segregation of polymorphic T-cell receptor genes in human families. Proc. Natl. Acad. Sci. U.S.A. 82: 3804-3808.

Robinson, M.A. and Kindt, T.J. 1987. Genetic recombination within the human T cell receptor a-chain gene complex. Proc. Natl. Acad. Sci. U.S.A. 84: 9089-9093.

Saito, H., Kranz, D.M., Takagaki, Y., Hayday, A.C., Eisen, H.N. and Tonegawa, S. 1984. Complete primary structure of a heterodimeric T-cell receptor deduced from cDNA sequences. Nature 309: 757-762.

So, A., John, S., Bailey, C. and Owen, M.J. 1987. A new polymorphic marker of the T-cell antigen receptor $a$ chain genes in man. Immunogenetics $25: 141-144$.

Vladutiu, A.O. and Rose, N.R. 1975. Cellular basis of the genetic control of immune responsive- 
ness to murine thyroglobulin in mice. Cell Immunol. 17: 106-113.

Wofsy, D., Ledbetter, J.A., Hendler, P.L. and Seaman, W.E. 1985. Treatment of murine lupus with monoclonal anti-T cell antibody. J. Immunol. 134: 852-857.

Yanagi, Y., Yoshikai, Y., Leggett, K., Clark, S.P., Aleksander, I. and Mak, T.W. 1984. A human $\mathrm{T}$ cell-specific cDNA clone encodes a protein having extensive homology to immunoglobulin chains. Nature 308: 145-149.

Yanagi, Y., Chan, A., Chin, B., Minden, M. and Mak, T.W. 1985. Analysis cDNA clones specific for human T cells and the $\alpha$ and $\beta$ chains of the T-cell receptor heterodimer from a human Tcell line. Proc. Natl. Acad. Sci. U.S.A. 82: 3430-3434.

Yoshikai, Y., Anatoniou, D., Clark, S.P., Yanagi, Y., Sangster, R., Van den Elsen, P., Terhorst, C. and Mak, T.W. 1984. Sequence and expression of transcripts of the human T-cell receptor $\beta$-chain genes. Nature 312: 521-524.

Yoshikai, Y., Toyonaga, B., Koga, Y., Kimura, N., Griesser, H. and Mak, T.W. 1987. Repertoire of the human $\mathrm{T}$ cell gamma genes: high frequency of non functional transcripts in thymus and mature T cells. Eur. J. Immunol. 17: 119-126. 